\title{
BALANCED USE OF RECREATION RESOURCES OF THE REGION: PUBLIC-MANAGEMENT ASPECT
}

\section{Tetiana Bezverkhniuk}

\section{INTRODUCTION}

Any conversions to the operation and development of a recreational facility or tourist product is generally associated with the use of recreational and economic resources that have price and value. That is why the task of rational use of scarce resources, including investment, arises. Recreation requires constant investment, so investment provision and investment activity play a very important role in this process. Since investments are a factor that provides not only functioning but also future development, for tourism and recreational sphere they are an indicator of its development. The key to the effectiveness of investing into the recreational sphere is the transformation of recreational resources into the investment potential of recreational areas.

At the same time, in practice, there is a difficulty in organizing the process of investing into the tourism industry, which is related both to the lack of complete information on the availability and status of all types of recreational resources on the territory and their potential, as well as to the process of planning, programming, designing the rational use of recreational resources and management of the development of recreational areas, taking into account the interests of all stakeholders.

In recent years, there has been a widespread and dynamic implementation of project-oriented management at the regional level in Ukraine, which is due, first of all, to the complexity of solving the problems of organizing the process of investing and designing the rational use of recreational resources in the face of rapid changes in the environment and time and resources scarcity. Usually, public authorities develop a significant number of programs and projects that 
compete with each other for limited resources, may be interrelated or complementary, aimed at achieving one or more strategic goals for the development of the region. The implementation of a large number of programs and projects of different degrees of complexity requires the use of specialized management technologies, among which portfolio management is a leading place.

However, portfolio management techniques and tools, that are successfully used in the business environment, may not always be appropriate for public use or require some modification. This is related both to the features of the management system and to the characteristics of the portfolio and projects - the portfolio components. Thus, the peculiarities of the use of portfolio management methods by public authorities are: the duration of the portfolio implemntation as a whole, due to the periods of implementation of the strategy of socioeconomic development of a certain region; multi-vector portfolio, which should include components that correspond to all areas of the territorial community life; resource specificity and limitations related to regulatory, economic, geographical and other factors, etc. In addition, there are specific requirements for the portfolio management process, due to the need to review and re-evaluate the portfolio in relation to local budget adoption, changes in leadership, general political situation in the country, etc. ${ }^{1}$.

Therefore, the scientific justification for a comprehensive approach to the management of recreational resources at the regional level is extremely relevant. In spite of the considerable scientific interest in the subject, there is in practice not yet a rational use of recreational resources, and recreational potential has not been evaluated at the regional level at all. All this actualizes the scientific study of the main conditions and features of the organization of

1 Chykarenko I.A. (2009) Portfeljnyj pidkhid v upravlinni proektamy: adaptacija do sfery municypaljnogho menedzhmentu [Portfolio approach in Project Management: adaptation to municipal management area]. Publichne administruvannja: teorija i praktyka, vol. 1(1). Available at: http://www.dridu.dp.ua/zbirnik/200901/Chikarenko_IStat.pdf (accessed 5 September 2019) 
effective recreational activity in the region and substantiation of a comprehensive approach to the rational use of resources.

\section{The role of public authorities in ensuring a balanced use of the region's recreational resources}

The scientific substantiation of a comprehensive approach to the management of recreational resources at the regional level, first, requires a clear definition of the role of regional authorities in the development of recreational activities.

In our view, regional management of recreation and tourism should be considered as: the activity of public authorities to create conditions for the rational and effective use of the region recreational potential; organizational and legal provision and practical implementation of the strategy/program for the development of recreational activities in the tourist sub-regions; regulation of subjectobject and subject-subject relations arising in the process of using recreational resources at the regional level, with the aim of ensuring the reconciliation of internal and external interests of different stakeholders of recreational activities, as well as their harmonization with the interests of the local population of tourist sub-regions (recreational zones) and the opportunities of the region.

For the effective functioning of the system of regional recreation and tourism management, the correct consideration is given to the principles of subsidiarity and compliance of the management entity with its object, which most closely reflect the regional specificity. That is, it should be, first, a study of the internal specifics, features, functions and potentials of the region recreational resources (as an object of regional management) inherent in the region's tendencies of recreational activities in order to alternatively select the optimal path of development of each recreational zone (tourist subregion) from taking into account generally recognized regional interests. This approach requires the identification of factors of formation of the regional situation of the recreation development and the development of a complex of models that reflect: recreational activity as a dynamic complex-organized hierarchical system; 
conditions of its components functioning; a recreational activity environment as an object of management ${ }^{2}$.

Under the regional situation of recreation development, we consider the state of all types of recreational resources within a certain territory in a certain period of time in order to identify the type of problems in recreational activity in the territory and its development trends. In this case, from the point of view of regional management, we can talk about the definition of recreational zones as territories of the region, in which a unique recreational situation is formed and a special program of development and specific mechanisms of state support are implemented. However, it should be noted that in such an approach, a recreational zone, such as a territorial (spatial) unit of a region, is not subject to direct influence by public authorities. The object of public management is the processes that occur within the recreational areas.

To ensure effective administrative actions by public authorities to optimize recreational activity at the regional level, it is advisable to carry out typification of recreational areas in the region. For example, for the typification of recreational zones of the Odesa oblast we have evaluated the following potential types:

-assessment of the natural and geographical recreational potential. The analysis of regional peculiarities of recreational potential formation was the basis for distinguishing the following factors of natural recreational resources: bioclimatic; geomorphological; structural elements of the ecological network, balneological and modern ecological status;

-assessment of socio-historical recreational potential. The experience of many countries around the world shows that historical and cultural sites can be decisive in shaping the demand for recreational resources and have a significant impact on revenue

${ }^{2}$ Edited by Izha M.M., Babov K.D., Bezverkhniuk T.M. (2016). Rehionalniy turystychniy produkt: proektniy pidkhid do zabezpechennya konkurentospromozhnosti [Regional tourism product: a project approach to ensuring competitiveness], Monograph. Press ORIDU, Odesa, 626 p. [Ukraine] 
generation. If the criteria and methodology for the assessment of natural recreational resources are well developed, there is no generally accepted scheme for the evaluation of historical and cultural resources. In order to determine the socio-historical recreational potential of the administrative regions of the Odesa oblast, an assessment was made of: cultural and historical recreational resources, natural and social recreational resources, event and attractional recreational resources;

-the assessment of investment recreational potential is based on a summary assessment of the potentials of infrastructure, finance, investment and the social component.

When analyzing recreational resources and determining the components of the recreational potential of the Odesa oblast, we paid attention to the fact that the nature of the placement of recreational facilities depends on the location of the infrastructure sites of attraction - in the conditions of the region, their placement determines the placement of recreational facilities. That is why we consider it advisable to pay attention to the potential of unused recreational resources in the process of identifying and typifying of recreational zones, which in our view is the basis for the effective development of recreation in the region.

In the Odesa oblast there is already formed a recreational complex, which represents a set of objects of recreation and infrastructure, which are focused on natural recreational resources. However, structural relationships were formed in the 1960's and 1970 's function poorly today. Changing development vector, systems of socio-economic relations, production depreciation of fixed assets cause insufficient efficiency of functioning of the region in the conditions of intensive development of world markets of recreational services. In the economy, this situation is seen as an increase in demand with a steady supply. This process cannot last endlessly, because if such a trend persists for a certain period of time, the proportion of consumers (tourists) are looking for other markets for services. A similar situation is currently present in the recreational space of Odesa. In order to overcome this development crisis, it is 
necessary to identify the untapped recreational potential of the region and justify the possibilities of reforming the sector.

The condition of effective spatial organization and development of the region is the use of untapped recreational potential. The study of the structure of available recreational resources shows their developed nomenclature, which is represented by natural-climatic, naturalanthropogenic and socio-economic potential. Modern types of recreation require a balanced use of untapped resources, for the formation of all-season recreation with different types of attractions. Priority research of modern recreation is to justify the spatial location of the resource base. It is advisable to carry out a comparative analysis of the spatial location of recreational resources and the intensity of functioning of the recreational sphere of the region in order to assess the potential for the placement of untapped recreational resources.

To make effective management decisions on the rational use of recreational resources in the region, it is necessary to have up-to-date, complete and comprehensive information on their current state. The most adequate reflection of the situation regarding the use of recreational potential and the development of recreational activity is the cartographic model, as a basis for creating a database and knowledge base on the structure, dynamics and organization of recreation in the territory of the region, its spatial and temporal hierarchy. That is, the fundamental scientific basis of a comprehensive approach to regional management of the development of recreation and tourism should be a knowledge base on a set of features, benefits, varieties that can be used to organize the process of investing in the recreational sector of the region.

The information component of a comprehensive approach to the management of recreational resources at the regional level should provide the necessary and sufficient inventory of data to compile a complete picture of the state and dynamics of development. To date, the amount of information that characterizes the quantitative and qualitative state of the elements of the recreational environment of the region reaches up to hundreds of indicators - they are collected, processed and accumulated by various entities of management and 
recreational activity. As a result, a huge amount of information is accumulated, which is difficult to coordinate with one another, is fragmentary, does not give a complete idea of the region recreational potential at all. That is, it is necessary to create such an information and infrastructure component of the model of recreational potential of the region, which would ensure the distribution of types and volumes of information received, legal legitimacy, completeness, authenticity, relevance, etc.

Assessment of the recreational potential of the territory serves as a basis for the adoption of effective management decisions to optimize, rationalize the spatial economic organization of territorial recreational systems, determine the value of individual resources, identify territorial differences in resource availability and identify ways of rational use of resources and balance by the regional authorities.

It should be emphasized that in the current conditions of decentralization, the dominant role of regional authorities in ensuring the strategic goals of regional development is the organization of an effective investment process, in particular in the recreational sphere. Investing in the recreational sphere is a process (a set of sequential actions) of attracting (motivating) an investor (or their totality) to investing investment resources in the creation / operation / development of recreational facilities in order to achieve the effective development of the recreational territory based on the harmonization of interests of participants in this process. which have beneficial socioeconomic effects and benefits, including expected profitability in the form of tangible income. Investing takes place through an investment project, the realization of which is organized according to the legally defined mechanism of investment activity.

\section{Determining the investment potential of the recreational area} is the basis for a balanced use of resources

The prospect of investing in the tourism and recreational sphere has been sufficiently substantiated with scientific papers and analytical documents. There is no doubt that global demand for wellness tourism 
is increasing. The key to the effectiveness of investing in the recreational sphere is the transformation of recreational resources into the investment potential of recreational areas.

Considering the peculiarities of investing in the recreational sphere, it is important to focus on the following ${ }^{3}$ :

1) recreational area (zone) is different from any other area in that it is a complete territory, different from other favorable for the development of recreation by the combination of natural conditions, resources and recreational objects. The development of a recreation area (zone) is not possible without the construction of roads, hotels and resorts, provision of the new recreational areas with necessary facilities, the creation of a park area and more. In this connection, one of the most important problems arises in ensuring the conditions of development of the recreational area (zone) - the limited investment resources for the implementation of long-term infrastructure projects;

2) it is possible to secure the inflow of investments into the recreational sphere of the region only by two means:

- direct - statutory regulation of investment activity (creation of preferential conditions and preferences for investors);

- indirect regulation based on the assessment of the investment attractiveness of the recreational area (zone) - the amount of capital investments that can be attracted to the recreational sector of the region based on the investment potential and the level of investment risks. Therefore, investment potential is the main indicator of the investment attractiveness of a recreational area.

The investment attractiveness of a recreational area (zone) is a set of objective prerequisites (features, factors, means) and opportunities of the recreational area that determine the demand for investments that can be attracted to the recreational sphere with the aim of its development, based on its inherent investment potential and the level of investment risks. In other words, the investment

${ }^{3}$ Edited by Herasymenko V.H. (2016). Otsinka turystychno-rekreatsiynoho potentsialu rehionu [Assessment of the tourist and recreational potential of the region], Monograph. Press ONEU, Odesa, 262 p. [Ukraine] 
attractiveness of the recreational area (zone) is a generalized characteristic of the investment potential of the territory in terms of prospects, benefits, efficiency from use and minimization of investment risks.

The investment potential of the recreational area can be viewed from two points of view, based on its components:

- formation of investment potential;

- usage of this potential.

The formulation of the task of developing a recreational territory may look like this: it is necessary to choose a development option in which the available potential allowed at least one way to achieve the expected results.

Formation and development of the investment potential of the recreation area occurs within certain limits or taking into account the principles that determine its use:

1. Taking into account the strategic goals of development of the region in the formation and expansion of the investment potential of the recreational territory. The size of the potential should be sufficient to ensure the development of the recreational area, in accordance with the chosen investment strategy;

2. Provision of flexibility of investment potential to influence of factors of internal and external environment, prompt reaction to changes of investment climate, emergence of new investment opportunities;

3. Ensuring diversified use of investment potential, facilitating the redistribution of unused resources between different investment projects ${ }^{4}$;

4. Consideration of the life cycle stage of the recreational area when using the investment potential.

${ }^{4}$ Komarova M.Ye. (2011), Metodologicheskiye podkhody $k$ otsenke turistskorekreatsionnogo potentsiala: regionalniy aspect [Methodological approaches to the assessment of tourist and recreational potential: regional aspect], Monograph. Press IPK NIU «BelGU», Belgorod, 144 p. 
In the conditions of globalization of economic processes against the background of market environment dynamism, the basis of stable development of recreational territory and its effective functioning becomes the choice of strategy of investment development taking into account the phase of the life cycle of the recreational territory.

Based on the analysis of successful international experience, we can identify the following effective strategies for investing in the development of recreational territory:

1) recreational territory of active attraction with sustainable development of tourist and recreational infrastructure - an innovative strategy focused on the development of the territory as a tourist destination, the formation of a complex recreational and tourist product and the development of a marketing model for its effective promotion to the domestic and world markets;

2) recreational territory with developed tourist and recreational infrastructure but with great potential of unused recreational resources - a motivational strategy aimed at improving the quality of tourism product and recreational services, forming a portfolio of investment projects for the development of new types of recreational product for the territory;

3) a recreational area with significant recreational potential, but with a pioneering level of tourism and recreational infrastructure development - a supportive strategy, a priority type of investment in clusters;

4) recreational territory with a unique set of recreational resources, but with a low level of tourist attractiveness - an evolutionary strategy focused on the creation of infrastructure for the use of a priority type of recreational resource with connection to the tourist routes network;

5) recreational territory of long-range development in the long term - an explanatory strategy, investing in the establishment of strategic and programmatic documents of development.

In order to evaluate the investment potential of the recreational area, one should consider such factors as:

- the ability to attract investors' attention; 
- availability of up-to-date proposals for investing into the project.

It should also be borne in mind that the investment potential of one area is very closely related to the potential of another one. Interconnected they form the investment potential of the region.

The main methodological approaches to the assessment of the investment potential of the recreational area and its components are the value approach, expert evaluation, evaluation based on a generic indicator, a comprehensive approach ${ }^{5}$.

It is important to emphasize that investment potential is a motive for which, besides the owner of the investment resources, the entities in need of investment should be involved. Therefore, this process requires targeted coordination.

In the process of assessing the investment potential of recreational areas, the case of the Odesa oblast, a comprehensive approach was used, which included a comprehensive assessment of investment potential by major groups of indicators. The assessment of investment potential was carried out using the balance method, which is the basis for the comparative analysis of the investment opportunities of the territory according to certain blocks of indicators, which are taken for equivalent categories.

Specific features that were taken into account in the process of assessing the investment potential of recreational territories of the Odesa oblast:

- selection of indicators (block 1 - production potential; block 2 - social potential; block 3 - financial potential) depended on information security: official statistics data and open data on sites of rayon state administrations;

5 Zdrenyk V. S. (2016), "Investytsiynyy potentsial: sutnist ponyattya ta problemy otsinky" ["Investment potential: the essence of the concept and problems of valuation"], journal Naukoviy visnyk Uzhhorodskoho universytetu [Uzhgorod University Scientific Bulletin], vol. 1, pp. 363-367. [Ukraine] 
- taking into account different units of measure and different directions of optimization, normalization of estimates was carried out for each selected indicator;

- the score for each of the blocks of indicators was carried out by summing the scores taking into account the coefficients of significance;

- each block consists of indicators that are adjusted by the coefficients of significance when it is necessary to reduce or increase the weight of the impact of the indicator on the overall assessment of the respective block, reflecting the degree of direct impact on investment processes in the recreational sphere. Thus, all indicators were divided into the main ones - key factors that should be weighted; neutral - significantly affect investment processes but do not need to increase in importance, and minor, which need to be reduced. The choice of significance coefficients reflects their corrective nature and does not allow significantly overlap the estimates;

- the distribution of points for each block depended on the maximum and minimum values in the blocks; the block integral estimate is calculated by geometric mean, which allows to take into account the multiplicative effect of the impact of indicators on investment processes.

Integral assessment of the investment potential of the recreational territories of the Odesa oblast allowed zoning of the territory with the allocation of 5 zones with priority investment strategies: 1) an innovative strategy focused on the development of the territory as a tourist destination; 2) a motivational strategy aimed at increasing the quality of tourism products and recreational services; 3) a supportive strategy with priority investment in clusters; 4) an evolutionary strategy focused on the creation of infrastructure for the use of a priority type of recreational resource with connection to the tourist routes network; 5) explanatory strategy, investing in the development of strategic and programmatic development documents.

The practical implementation of the investment model of complex development of recreational territories of the Odesa oblast is 
connected, first of all, with the use of investment resources of the territories that have their price and value. Therefore, the main principle of the model implementation is the principle of rational use of limited investment resources.

The aggregate of all resources of the recreation area, capable of ensuring the stable growth of the main socio-economic indicators, is its investment potential, the current level of which is a decisive factor in the selection of types of investments and investment objects. Therefore, taking into account the principle of rational use of investment resources, priority areas of investment are those that will ensure the effective implementation of the recreational zone of its main recreational functions. The introduction of the investment model will increase the investment potential of the recreational territory, which will make it possible to implement projects focused on ensuring the fulfillment of the territory by its functions, and, subsequently, the development of the territory as a tourist destination, the formation of a comprehensive recreational and tourist product and its effective promotion to the world tourist market.

Based on the above principles, depending on: life cycle stage of the recreational area; the level of its investment potential; major and minor recreational functions; defined investment strategies; the availability of unused resources, the investment objects were divided into groups:

- short term prospective investment objects, which are in line with the strategy of development of the recreational area in terms of its basic recreational function, and for which both investment potential and recreational resources are available; as well as facilities that provide additional functions - only in the case of territories with sufficient investment potential (group of investment objects $1^{\text {st }}$ queue);

- medium-term prospective investment objects, that are consistent with the recreational territory development strategy in terms of performing secondary functions for which recreational resources are available, but investment potential is insufficient at present; relevant investment projects can be implemented under conditions of 
sustainable development of the recreational area and increase of its investment potential; for areas with sufficient investment potential, projects aimed at using untapped resources are also possible (group of investment objects $2^{\text {nd }}$ queue);

- long-term prospective investment objects, that are in line with the development strategy of the recreational area in terms of performing secondary functions for which untapped resources are available (or additional research is needed to identify and measure the recreational value of those resources), but insufficient investment potential (group of investment objects $3^{\text {rd }}$ queue).

The complexity of solving the tasks of organizing the process of transformation of recreational resources into the investment potential of recreational territories determines the expediency of implementing methods of portfolio management of investment projects into the practical activity of the regional authorities.

\section{Project-oriented management of balanced use of recreational resources}

Today, one of the most efficient approaches to organizing a balanced use of recreational resources is project management within the tourist and recreational destination. After all, a tourist and recreational destination is an integrated set of various investment projects for the creation of objects of recreation, leisure and entertainment; development of local transport and communications; formation of health and tourism infrastructure; marketing program implementation, etc.

Project management has undeniable benefits. However, there are also issues that are related, first of all, to the limited life of the project, its seclusion and isolation. A project is the best tool for achieving a specific goal. The most important task is precisely the formulation of the project purpose, the peculiarity of which is that the implementation of the goals of individual projects in the aggregate ensures the fulfillment of strategic objectives of the destination as a whole. When implementing a large number of projects that are combined for a single strategic purpose, it is important to evaluate 
each project individually and evaluate the overall program or portfolio of projects. In particular, it is necessary to initiate each project and, once completed, adopt its results in line with the strategic goals. Also important for the implementation of a large number of projects is the rational distribution and redistribution of recreational resources between individual projects. In case of resources scarcity, it is necessary to organize their redistribution taking into account the priority of projects. A decision may also be taken to suspend, close the postponement of certain projects in view of changes in the portfolio/ program environment, shift market focus, refine strategy, etc. Finally, purposeful collection, accumulation, analysis and synthesis of the results of individual projects is necessary.

Therefore, effective management of destination development projects (recreational zone), compensation for isolation and limited project life require continuous integrative activities. Each of these projects does not exist by itself, but only in cooperation with others, the joint implementation of which will allow to achieve a strategic goal or a higher level goal. These projects form a comprehensive Recreational Area Development Program, which is no longer a set of activities, but a set of interrelated projects of various types: financial, organizational, technological, technical, marketing, infrastructure selected for implementation based on common selection criteria. The following is the division of projects between the sectoral enterprises of the tourist and recreational sphere and the formation of clusters responsible for the implementation of a portfolio of projects tied to a specific territory.

A portfolio is a set of projects or programs and other work combined to manage effectively these works to achieve strategic goals ${ }^{6}$. The concepts of portfolio of projects and program are close. Like the portfolio of project, the program brings together a number of

${ }^{6}$ Sencha I.A. (2016) Obghruntuvannja optymaljnosti portfeljnogho pidkhodu pry realizaciji antykryzovykh strateghij [Justification of the portfolio approach optimality in the implementation of the anti-crisis strategies]. Derzhava ta reghiony. Ser.: Derzhavne upravlinnja, vol. 2(54), pp. 20-24 
projects and programs, as well as individual works outside the projects, to coordinate and effectively manage them together. However, all projects included in the program are interconnected and interdependent, all aimed at achieving a common goal, and projects and programs included in the portfolio are not necessarily interdependent or directly related, they are combined in time and in part terms of implementation.

In order to understand the importance of implementing portfolio management to ensure a balanced use of recreational resources, it is important to emphasize its fundamental difference from project management. That is, if the purpose of managing an individual project is to create a product in a timely manner and within budget, then the purpose of portfolio management is to obtain the greatest return on the implementation of the entire set of projects. Implementation of portfolio of projects is focused on the achievement of strategic goals on the set of completed portfolio of projects.

From a strategic management perspective, projects are tools for solving the tasks obtained as a result of the decomposition of a strategy. To improve project management of implementation of strategies, they create portfolios / programs of projects. Therefore, the main difference between a portfolio of projects is its strategic orientation. Combining projects in a portfolio allows you getting a new quality of management, enhance the overall effect of project implementation, and the portfolios of project themselves become one of the most effective mechanisms for strategic management of the development of tourist and recreational destinations.

Thus, the portfolio approach to the management of the tourist and recreational destination development involves: prioritization of projects in accordance with the strategic objectives of the territory development; allocation of resources between projects according to priorities.

The selection of projects into the strategic portfolio involves the following:

- determination of the optimal and acceptable number of projects in the portfolio; 
- ensuring, that projects are consistent with strategic plans.

Thus, the organization of an adequate system for managing the strategic portfolio of projects of tourist and recreational destinations development creates a number of significant advantages:

- implementation of potential projects in terms of their value and benefits to stakeholders in accordance with current strategic goals;

- determination of the optimal or acceptable number of projects in the portfolio;

- ensuring, that projects are consistent with strategic plans;

- provision of different projects types balancing in terms of goals and benefits, provision of opportunities, benefits and risks balancing.

In the aspect of our research, the fundamental issue is the responsibility for the formation, management and implementation of a portfolio of tourism and recreation destination development projects. Naturally, it should be a local public authority, which is legally responsible for formulating strategic priorities and programs for the territory development. However, the key to portfolio management is the competence of the staff and the level of maturity of the organization implementing the project approach.

Elaborationg a strategy for tourism development and recreation in the region, an appropriate structural subdivision of a public authority, when planning new strategic goals, should consider them through the prism of the project approach. For example, in the next 3 years it is planned to launch a new sanatorium and resort complex, to open 10 new cultural and entertainment centers, to improve the transport network and to reposition the brand of the resort area. If all these projects are really considered as projects and if there are 45 such projects, then the question of priority arises. How to define them, how to manage them in dynamics? In addition, if in the tourist market the situation (demand change) suddenly changes - do we leave the project, do we exclude it from the list of strategic and priority ones, or continue? 
Indeed, sometimes strategic goals can be achieved less than initially planned by the number of projects in the portfolio. On the other hand, the decision to stop an important project may affect other projects and halt the overall growth of the destination for years to come. In order to understand such opportunities, risks and threats, an appropriate organizational structure is required - the Project Portfolio Management Office (Strategic Tourism Development Board).

Strategic project portfolio management processes can be summarized in two main categories:

- monitoring and control of the whole portfolio. This process is necessary to confirm that the implementation of the projects is in line with the strategic goal of the destination development, ensures the efficient use of resources and investments;

- assessment of strategic changes, decision making. During the life cycle of the portfolio, there are constant changes in the external and internal environment of the destination. These changes significantly affect the definition of success criteria and policy benchmarks. For example, a change in senior management may lead to the setting of new strategic goals, a change in the current market situation may affect the cost and timing of output of portfolio projects. Accordingly, strategic goals and priorities should be reviewed on an ongoing basis. The portfolio needs to be re-viewed and balanced.

Today, in Ukraine, strategic planning for the tourism industry development has already been properly evaluated, and managers recognize the important role of professional management of programs/ portfolios, starting with defining the strategy for the development of tourism and recreational sphere and ending with the implementation of individual projects. However, a common misconception is that many do not pay attention to the clear relevance of the portfolio of projects to the development strategy.

Creating strong links between strategy and multiple projects allows you maximizing value and achieving optimal focus on turning the strategy into life. Nevertheless, most often the links between 
strategy and projects are the weakest points in the tourism management system in Ukraine.

\section{CONCLUSIONS}

The study of the main conditions and features of the organization of effective recreational activity at the regional level has made it possible to prove that the regional management of recreation and tourism should be considered as the activity of public authorities to create conditions for the rational and effective use of the recreational potential of the region. Proper consideration of the subsidiarity principles and the entity's compliance with the entity that most closely reflect regional specificity is of paramount importance. The information component of a comprehensive approach to the management of recreational resources at the regional level should provide the necessary and sufficient inventory of data to compile a complete picture of the state and dynamics of development.

Emphasizing the effectiveness of implementing portfolio management as a technology capable of ensuring a balanced use of recreational resources through the implementation of a set of strategic-oriented investment projects, it is important to focus on the following. There are at least four groups-directions of investments in the recreational sphere: investments aimed at nature conservation; investments that are renewable in nature; investments of a capital nature, that is, in the acquisition or manufacture of the tangible and intangible assets of the tourist and recreational infrastructure on their own use; investments in the development of new innovative types of recreation and tourism, the development and implementation of innovative technologies aimed at improving customer service and expanding service opportunities. If there are investment projects in the development portfolio of the recreational zone in all four directions, it is possible to ensure a balanced use of recreational resources and to predict the effective implementation of strategic goals. 


\section{SUMMARY}

In the article, based on the study of the main conditions and peculiarities of the organization of effective recreational activity on the case of the Odesa oblast, it is proved that modern types of recreation require balanced use of resources for the formation of all-season recreation with different types of attractions. It is substantiated that regional management of recreation and tourism should be considered as an activity of public authorities to create conditions for rational and effective use of the recreational potential of the region. It has been emphasized that transformation of recreational resources into the investment potential of recreational territories is the key factor to the effectiveness of investing in the recreational sphere. Effective strategies for investing in the recreational sphere have been identified. It is proved that one of the most effective approaches to the organization of balanced use of recreational resources is portfolio management within the tourist and recreational destination.

\section{REFERENCES}

1. Chykarenko I.A. (2009), "Portfeljnyj pidkhid v upravlinni proektamy: adaptacija do sfery municypaljnogho menedzhmentu” ["Portfolio approach in Project Management: adaptation to municipal management area"], journal Publichne administruvannja: teorija $i$ praktyka [Public administration: theory and practice], vol. 1, pp. 1723. [Ukraine]

2. Edited by Izha M.M., Babov K.D., Bezverkhniuk T.M. (2016). Rehionalniy turystychniy produkt: proektniy pidkhid do zabezpechennya konkurentospromozhnosti [Regional tourism product: a project approach to ensuring competitiveness], Monohraph. Press ORIDU, Odesa, 626 p. [Ukraine]

3. Edited by Herasymenko V.H. (2016). Otsinka turystychnorekreatsiynoho potentsialu rehionu [Assessment of the tourist and recreational potential of the region], Monohraph. Press ONEU, Odesa, 262 p. [Ukraine]

4. Komarova M.Ye. (2011), Metodologicheskiye podkhody $k$ otsenke turistsko-rekreatsionnogo potentsiala: regionalniy aspect 
[Methodological approaches to the assessment of tourist and recreational potential: regional aspect], Monograph. Press IPK NIU "BelGU", Belgorod, $144 \mathrm{p}$.

5. Zdrenyk V. S. (2016), "Investytsiynyy potentsial: sutnist ponyattya ta problemy otsinky" ["Investment potential: the essence of the concept and problems of valuation"], journal Naukoviy visnyk Uzhhorodskoho universytetu [Uzhgorod University Scientific Bulletin], vol. 1, pp. 363-367. [Ukraine]

6. Sencha I.A. (2016), "Obghruntuvannja optymaljnosti portfeljnogho pidkhodu pry realizaciji antykryzovykh strateghij" ["Justification of the portfolio approach optimality in the implementation of the anti-crisis strategies"], journal Derzhava ta reghiony [State and regions], vol. 2 (54), pp. 20-24. [Ukraine]

\section{Information about the author: Tetiana Bezverkhniuk,}

Doctor of Sciences in Public Administration, Professor,

Chair of the Project Management Department, Odessa Regional Institute for Public Administration of the National Academy for Public Administration under the President of Ukraine 22, Henuezka str., Odesa, 65009, Ukraine ORCID ID: orcid.org/0000-0002-2567-8729 